\title{
Effect of flooding on survival and initial growth of Ocotea pulchella (Nees) Mez. seedlings in semi-controlled light conditions
}

\author{
Luciana Andrea Pires ${ }^{1}$ and Victor José Mendes Cardoso ${ }^{2,3}$
}

Recebido em 9/08/2010. Aceito em 13/05/2011

\begin{abstract}
RESUMO
(Efeito do alagamento na sobrevivência e crescimento inicial de Ocotea pulchella (Nees) Mez. em condições semi controladas). Considerando-se a ocorrência de Ocotea pulchella em áreas sujeitas a alagamentos periódicos, neste trabalho estudou-se a sobrevivência e desenvolvimento inicial de plântulas (dois meses de idade) e juvenis (nove meses de idade) de $O$. pulchella em resposta a alagamento sob diferentes regimes luminosos, variando-se tanto a qualidade como a quantidade de luz, com o objetivo de se verificar a influência desse fator sobre a resposta ao alagamento. Foram testados três níveis de água no solo (capacidade de campo, alagamento médio - este apenas em plântulas - e alagamento total) e quatro níveis de luz (pleno sol, sombreamento neutro, sombreamento enriquecido com vermelho extremo e sombreamento neutro mais vermelho extremo). A sobrevivência das plântulas e juvenis ao longo de um ano foi relativamente alta, ao passo que o crescimento foi afetado negativamente em pleno sol e alagamento, dependendo das condições de luz. O crescimento de plântulas foi inibido pelo alagamento de solo, independentemente das condições de luz, enquanto que os resultados foram similares nas plantas submetidas a alagamento médio e capacidade de campo. O alagamento também inibiu o crescimento de juvenis, sendo que as respostas das plantas praticamente não foram afetadas pelos regimes de luz. Os resultados sugerem que plântulas de O. pulchella podem sobreviver no sub-bosque, mesmo em áreas sujeitas a alagamento, formando um banco de plântulas de crescimento lento. A espécie parece tolerar o alagamento do solo por tempo relativamente prolongado, quando não está sob luz direta. Por outro lado, algumas respostas ao sombreamento, de plantas submetidas a inundação, parecem ser afetadas pela quantidade e qualidade da luz.
\end{abstract}

Palabras clave: Floresta de Restinga, juvenis, alagamento, desenvolvimento

\begin{abstract}
(Effect of flooding on survival and initial growth of Ocotea pulchella (Nees) Mez. seedlings in semi-controlled light conditions). Taking into account the occurrence of Ocotea pulchella in areas subjected to periodic flooding, this work aimed to evaluate the survival and initial development of Ocotea pulchella seedlings ( 2 months old) and juveniles ( 9 months old) in response to waterlogging under different light regimes by varying both light quantity and light quality, in order to test for possible flood tolerance of the species as affected by light conditions. Three levels of soil moisture (field capacity, mean flooding - only for seedlings - and full flooding) and four light treatments (full sun, neutral shade, far red enriched shading and neutral plus far red) were tested. The survival of seedlings and juveniles during one year was relatively high, whereas growth was negatively affected by full sun and flooding. Seedling growth was inhibited by soil waterlogging whatever the light condition, whereas plant growth at field capacity and mean flooding was similar. Flooding also inhibited the growth of juveniles, and that response was practically not affected by the light regimes. The results suggest that Ocotea pulchella seedlings can survive in the understory, even in areas subject to flooding, forming a slow-growth seedling bank. The species seems to tolerate relatively long-term soil waterlogging when kept out of direct sunlight. Otherwise, responses of waterlogged plants to shading seem to be affected by irradiance and light quality.
\end{abstract}

Key words: Restinga forest, juveniles, waterlogging, development

1 Universidade Norte do Paraná, Centro de Ciências e Tecnologia, Londrina, PR, Brazil

2 Universidade Estadual Paulista Julio de Mesquita Filho, Instituto de Biociências, Departamento de Botânica, Rio Claro, SP, Brazil

3 Author for Correspondence: victorjc@rc.unesp.br 


\section{Introduction}

Plant growth is an integrated response controlled by interactions of genotype and environmental factors such as light and water. Montgomery and Chazdon (2002) report that several studies demonstrate that light availability on the forest floor plays an important role in growth, survival and life history of tree seedlings and saplings, with some species being able to germinate and grow below a canopy, whereas others need some increase in solar radiation for growth. Although several reports have studied the effect of shade on the growth of tree species, most have focused only on the effects of decreasing the irradiance (Souza \& Valio 2003) and did not take into account the changes in light quality (red/ far red ratio). In fact, the "shade" under the forest canopy is characterized both by a decrease of the photon flux density and the red/far-red ratio, and most of the field studies on the effect of natural shading do not discriminate between light quantity and light quality, although they may be of some advantage when interpreting the effects of shade on growth, since the concept of shade-tolerance does not discriminate between these effects (Souza \& Valio 2003).

Distribution and growth of woody plants also depend on water supply and both species composition and productivity are sensitive to too little or too much water. Continuous or temporary flooding of forest ecosystems leads to soil anaerobiosis and consequent number of soil and plant changes that adversely affect growth. Typical responses of unadapted species subjected to flooding include decrease in growth as well as changes in plant morphology and anatomy (Kozlowsky \& Pallardy, 1997, Lobo \& Joly 1995). Responses to flooding vary with species, age of plants, stage of development, condition of the floodwater, and time and duration of flooding (Kozlowsky \& Pallardy, 1997). Relatively few studies have addressed the response to flooding of woody species as affected by light conditions. Some reports suggest that the species response to soil water status can be changed by shading, although the effect of water treatment seems to be dominant over that of irradiance (Dale \& Causton 1992; Ferreira et al. 1991).

Ocotea pulchella (Nees) Mez (Lauraceae) is a semi-deciduous to perennial tree, widely distributed from seasonal forests in the states of Espirito Santo, Minas Gerais and Mato Grosso do Sul, to Rio Grande do Sul, and riparian forests in the state of São Paulo (Rodrigues \& Naves 2001, Carvalho 2006), as well as in Cerrado (Durigan et al. 2002, Francisco \& Galetti, 2002) and Restinga areas (Sugyama 1998, Silva $\&$ Britez 2005). The species was classified as anthropogenic pioneer, early secondary, late secondary or climax shadetolerant (Salimon \& Negrelle 2001, Carvalho 2006), which implies its occurrence both within the forest and forest edge. Ocotea pulchella grows naturally in the coastal area in organic, moist to wet, soils, and it is abundant in the vicinity of permanently flooded areas (Carvalho 2006). It has been found that both size and abundance of O. pulchella in
Restinga forests can vary depending on local characteristics, suggesting that plant development is affected by physical factors of the environment.

Taking into account that the plant establishment involves survival and initial growth and is one of the most critical phases for the regeneration of forests, several studies have addressed the effect of different environmental factors on seedling establishment of tropical species in natural conditions as well as under controlled or semi-controlled conditions (Walker \& Chapin 1986), with the latter being advantageously employed to study mechanisms by which environmental fluctuations affect the growth of plants (Kozlowski \& Pallardy 1997). This work aimed to evaluate the survival and development of Ocotea pulchella seedlings and juveniles in response to waterlogging under different light regimes varying both light quantity and light quality in order to test for possible flood tolerance of the species as affected by light conditions.

\section{Material and methods}

Ocotea pulchella plants of two age groups (2 months and 9 months old) here named "seedlings" and "juveniles", respectively, were used in the assays. Seedlings were obtained from seeds collected in Parque Estadual da Ilha do Cardoso (PEIC) and sowed in plastic trays filled with the commercial substrate Plantmax ${ }^{\mathrm{TM}}$ and grown in Green House for approximately two months before being transplanted to $0.5 \mathrm{~L}$ plastic cups filled with an "organic" (Table 1) substrate. Juveniles were obtained from Viveiro Municipal de Ilha Comprida-SP, where they were cultivated in a mix of vermiculite $(15 \%)$, rice shells $(15 \%)$, peat $(40 \%)$ and restinga soil (30\%) enriched with fertilizer and grown under full sunlight. The juveniles plants were transplanted to $1.5 \mathrm{~L}$ plastic bags filled with organic substrate (Table 1) and kept under natural shade (average irradiance of $\pm 12.5 \mu \mathrm{mol} . \mathrm{m}$ ${ }^{2} . s^{-1}$ at noon) for two months before the start of the assays.

The assays were carried out at the Experimental Garden (JE) of Instituto de Biociências, Unesp, Rio Claro, SP. The climate of Rio Claro is of the Cwa type by the Koeppen system, characterized by a dry (April-September) and a wet (October-March) season. For the treatments, the potted plants were placed in 32L plastic boxes (five seedlings or juveniles per box, and three boxes per treatment) and submitted to the following water treatments: field capacity (fc); mean flooding $(\mathrm{m})$; and fully flooded $(\mathrm{w})$. The plants from each water treatment were divided into four groups corresponding to the following light conditions: full sunlight $(\mathrm{S})$; neutral shade $(\mathrm{Sb})$; "far red" enriched environment $(\mathrm{F})$; and neutral shade + far-red (SF). For "fc" treatments the vessels were laid on a layer of water $\leq 2 \mathrm{~cm}$ deep covering the bottom of the box, in order to keep the substrate saturated. For the " $m$ " condition the vessels were kept partially submerged and the water covered only $50 \%$ of the substrate, whereas in the " $w$ " treatments the entire substrate was immersed in the 
Table 1. Chemical analysis of substrate used for Ocotea pulchella seedlings and juveniles held in Experimental Garden.

\begin{tabular}{lcccccccc}
\hline & $\mathrm{pH}$ & $\begin{array}{c}\mathrm{C} \\
\mathrm{g} \cdot \mathrm{dm}^{-3}\end{array}$ & $\begin{array}{c}\mathrm{N} \\
(\%)\end{array}$ & $\begin{array}{c}\mathrm{P} \\
\mathrm{mg} \cdot \mathrm{dm}^{-3}\end{array}$ & $\begin{array}{c}\mathrm{K} \\
\mathrm{mmol} \cdot \mathrm{dm}\end{array}$ & $\begin{array}{c}\mathrm{Ca} \\
\mathrm{mmol} \cdot \mathrm{dm}^{-3}\end{array}$ & $\begin{array}{c}\mathrm{Mg} \\
\mathrm{mmol}^{-} \mathrm{dm}^{-3}\end{array}$ & $\begin{array}{c}\mathrm{S} \\
\mathrm{mmol} \cdot \mathrm{dm}^{-3}\end{array}$ \\
\hline seedlings & 5,1 & 36 & 0,4 & 0,17 & 0,17 & 0,63 & 0,7 & 0,63 \\
juveniles & 4,7 & 57,5 & 0,4 & 0,16 & 0,34 & 0,91 & 0,83 & 0,51 \\
\hline
\end{tabular}

water. The juveniles were not submitted to the "m" condition due to the small number of plants available. Irradiance (PAR) was measured with a LI-1000 (LiCOR) radiometer, and the red:far-red ratio (R:FR) measured with a LiCOR spectroradiometer. In the "full sunlight" treatments the plants were exposed to direct sunlight (irradiance of 1816 $\mu \mathrm{mol} \cdot \mathrm{m}^{-2} \cdot \mathrm{s}^{-1}$, and R:FR of 1.27); the neutral shade condition was assured by maintaining the plants under a layer of black nylon screen $50 \%$ shade Sombrite ${ }^{\mathrm{TM}}\left(792 \mu \mathrm{mol} \cdot \mathrm{m}^{-2} \cdot \mathrm{s}^{-1}\right.$ and $\mathrm{R}: \mathrm{FR}=1.27)$. For the far-red enriched environment and the "shade + far-red" treatment the vessels were covered with a layer of fabric, color purple, called "failet" resulting in $89 \%$ shade $\left(192 \mu \mathrm{mol} \cdot \mathrm{m}^{-2} \cdot \mathrm{s}^{-1}\right.$ and R:FR $\left.=0.3\right)$, and an internal layer of Sombrite ${ }^{\mathrm{TM}}$ plus an external layer of failet bringing about $98 \%$ shade $\left(34 \mu \mathrm{mol} \cdot \mathrm{m}^{-2} \cdot \mathrm{s}^{-1}\right.$ and $\left.\mathrm{R}: \mathrm{FR}=0.3\right)$, respectively. From now on the treatments "full sun", 50\% shade, $89 \%$ shade and $98 \%$ shade will be referred to as S, $\mathrm{Sb}, \mathrm{F}$ and SF, respectively.

The variables survival (percentage of living plants), leaf area and height (distance between the stem collar and the apex) were assessed in all plants every three months up to 360 days, whereas dry mass was estimated only after three and 12 months from the start of the assay from samples of three plants selected randomly. Leaf area was estimated from the equation $\mathrm{Y}=0.395+149 . \mathrm{X}$, where $\mathrm{Y}$ is the length of the main vein times the maximum width of the leaf, and $\mathrm{X}$ is leaf area. The equation was obtained from the relation between leaf area (measured by scanning with the software PXAREA ) and Y $\left(r^{2}=0.98\right)$. The variables "Relative Growth Rate" (RGR), "Net Assimilation Rate" (NAR), "Specific Leaf Area" (SLA), "Leaf Area Ratio" (LAR) and "Leaf Weight Ratio" (LWR) were calculated according to Hunt (1982).

The data were submitted to factorial analysis of variance, followed by Tukey test for comparisons of means. If necessary, raw data were transformed into the respective angular values (for percentages) or logarithms (for the other variables); however, if the transformed data did not meet the assumptions for parametric analysis, Kruskal-Wallis analysis of variance was used (Zar 1996). The linear correlation analysis based on Pearson's $r$ statistic, which measures the correlation degree to which two variables are related, was also used.

\section{Results}

In general, the percentage of seedlings that remained alive throughout the assay were relatively high (Figure 1) and no response of the plants to flooding was observed, except for the $\mathrm{F}$ treatment (Figure $1 \mathrm{E}$ ) in which the percentage of survivors decreased after 12 months in 'w'. Otherwise the percentage of survivals decreased after nine months of assay in seedlings kept at $\mathrm{S}$, whereas in the shaded ( $\mathrm{Sb}, \mathrm{F}$ and SF) plants the percentage of live seedlings in general changed very slightly throughout the assay (Figures 1C, E, $\mathrm{G})$. The mean percentage of juveniles alive at ' $\mathrm{fc}$ ' was nearly constant during the entire 12-month period, and waterlogging caused a decrease in the number of survivors in all the light treatments (Figures 1B, D, F, H), although the effect appeared to be more pronounced in plants covered only with failet (Figure 1F). Seedling survival correlated $(\mathrm{p}<$ 0,05 , Pearson) only with RGR in height $(r=0.54)$, whereas juvenile survival correlated with RGR in number of leaves $(\mathrm{r}=0,71)$, RGR dry mass $(\mathrm{r}=0,75)$, NAR $(\mathrm{r}=0,73)$, leaf area $(\mathrm{r}=0,60)$ and LWR $(\mathrm{r}=0,53)$.

Height growth of Ocotea pulchella seedlings did not change at ' $w$ ' whatever the light condition, while at ' $f$ ' and ' $\mathrm{m}$ ' height increased only in shaded (Sb, F and SF) plants (Figure 2). No change in height was observed for juveniles kept flooded throughout the assay, while at ' $f c$ ' a growth in height was observed only in plants kept in far red enriched shading (Figure 2).

Similarly to height growth, the shoot and root dry mass of seedlings practically did not change, or increased slightly, over the first three months, and few differences were found among the water treatments (Figures $3 \mathrm{~A}, \mathrm{C}$ ). After one year of assay (Figures 3B, D), both shoot and root dry mass were significantly inhibited for seedlings at ' $w$ ', as compared to ' $\mathrm{c}$ ' and ' $\mathrm{m}$ ', only under $\mathrm{Sb}$. In seedlings maintained both in far-red enriched environment and S (Figures 3B, D) there was no difference among the soil water regimes. Full flooding inhibited shoot dry weight of juveniles in all of the light treatments (Figure 4A) and had little or no effect on root dry weight (Figure 4C) after three months, while the inhibitory effect of flooding became more pronounced after 12 months (Figures 4B, D). The dry mass of juveniles in flooded regime remained practically constant over the entire 12-month period (Figure 4).

In seedlings kept at $S$ for 12 months, waterlogging caused an increase of the root-to-shoot dry mass ratio (R:S) as compared to the ' $m$ ' and ' $f$ ' treatments, while in plants maintained under SF the R:S was reduced in ' $w$ ' $(H=25,9 ; p=0,007$; Kruskal-Wallis test). In juveniles grown at neutral shade, the $\mathrm{R}: \mathrm{S}$ was higher at ' $\mathrm{f}$ ' than at flooding, while under SF covering the R:S was lower in the former than in the latter (Table 2).

Leaf area of seedlings grown in ' $w$ ' substrate was significantly lower than in both ' $\mathrm{cc}$ ' and ' $\mathrm{m}$ ' treatments only in 

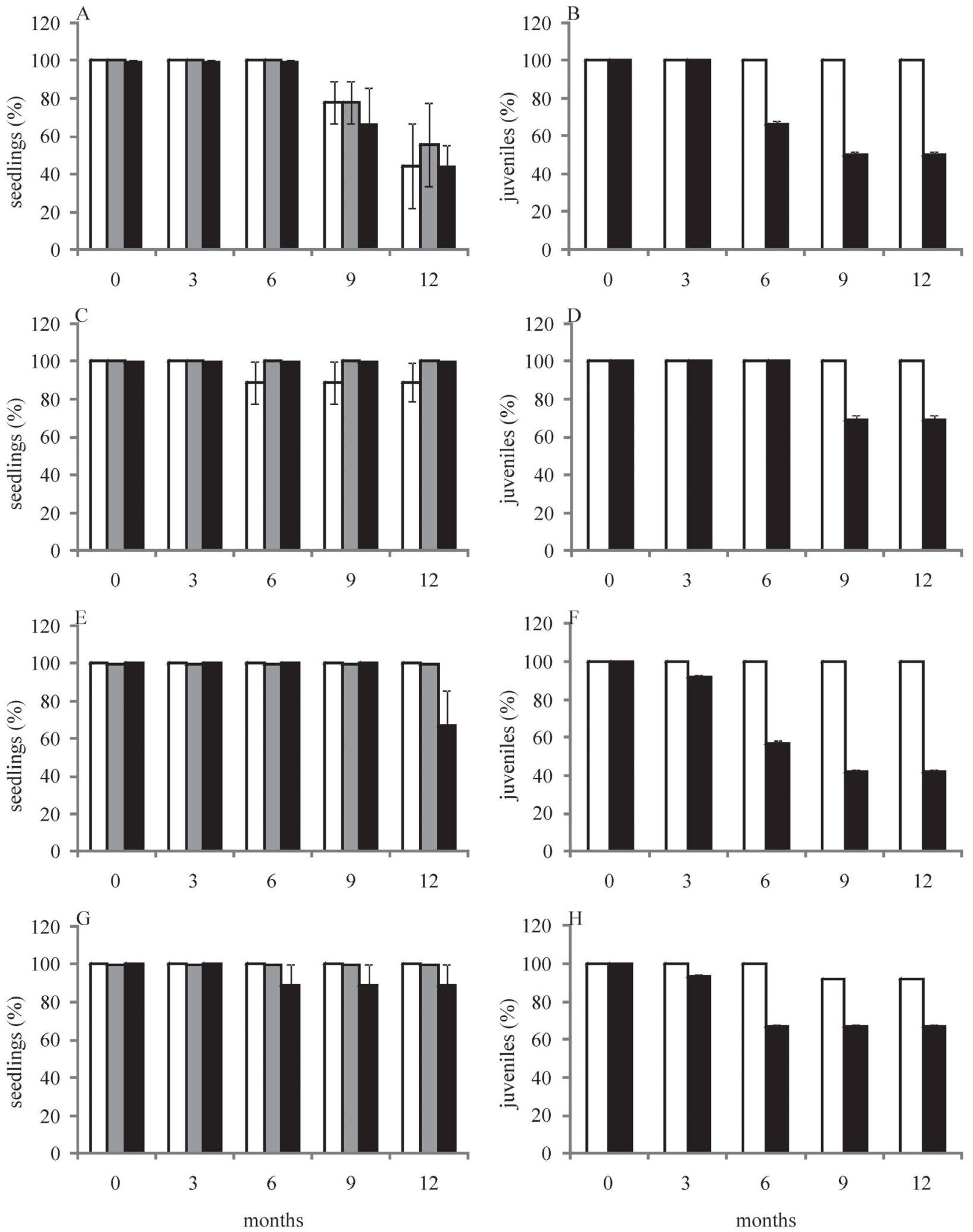

Figure 1. Survival percentage of seedlings (left graphics) and juveniles (right graphics) of Ocotea pulchella grown in S (A, B), Sb (C, D), failet (E, F) and SF (G, H), and kept at field capacity (white bars), mean flooding (grey bars, seedlings only) and full flooding (black bars) water regimes. Means \pm SE. S: $100 \%$ irradiance, R:FR $=1.27$; Sb: $50 \%$ shade, R:FR $=1.27 ;$ F: $89 \%$ shade, R:FR $=0.3$; SF: $98 \%$ shade, R:FR $=0.3$. 

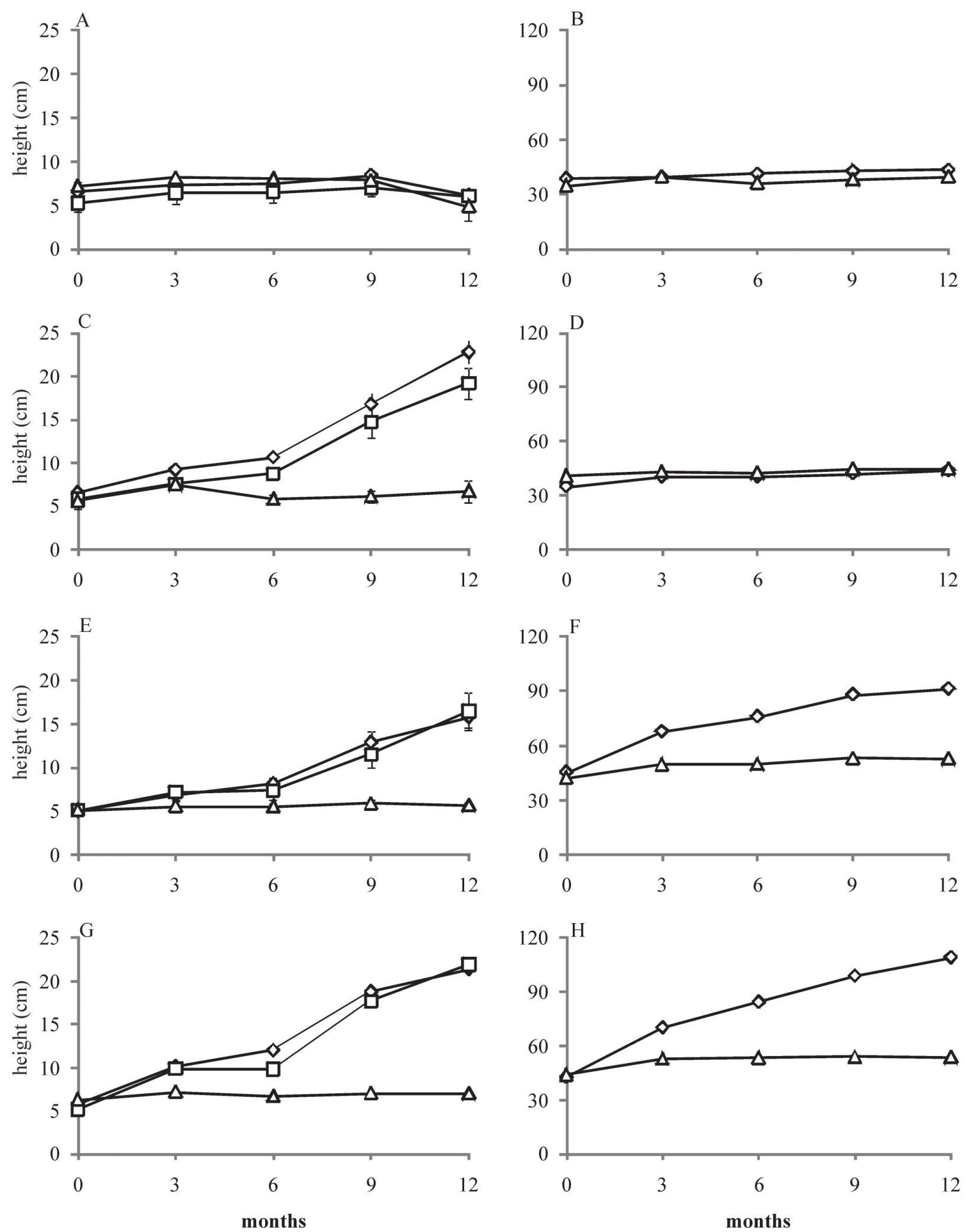

Figure 2. Time course of height of Ocotea pulchella seedlings (left graphics) and juveniles (right graphics) grown in S (A, B), Sb (C, D), failet (E, F) and SF (G, H), at field capacity $(\diamond)$, mean flooding $(\square)$ and full flooding $(\Delta)$. Means \pm SE. S: $100 \%$ of irradiance, R:FR $=1.27 ;$ Sb: $50 \%$ shade, R:FR $=1.27$; F: $89 \%$ shade, R:FR $=$ 0.3 ; $\mathrm{SF}$ : $98 \%$ shade, $\mathrm{R}: \mathrm{FR}=0.3$. 

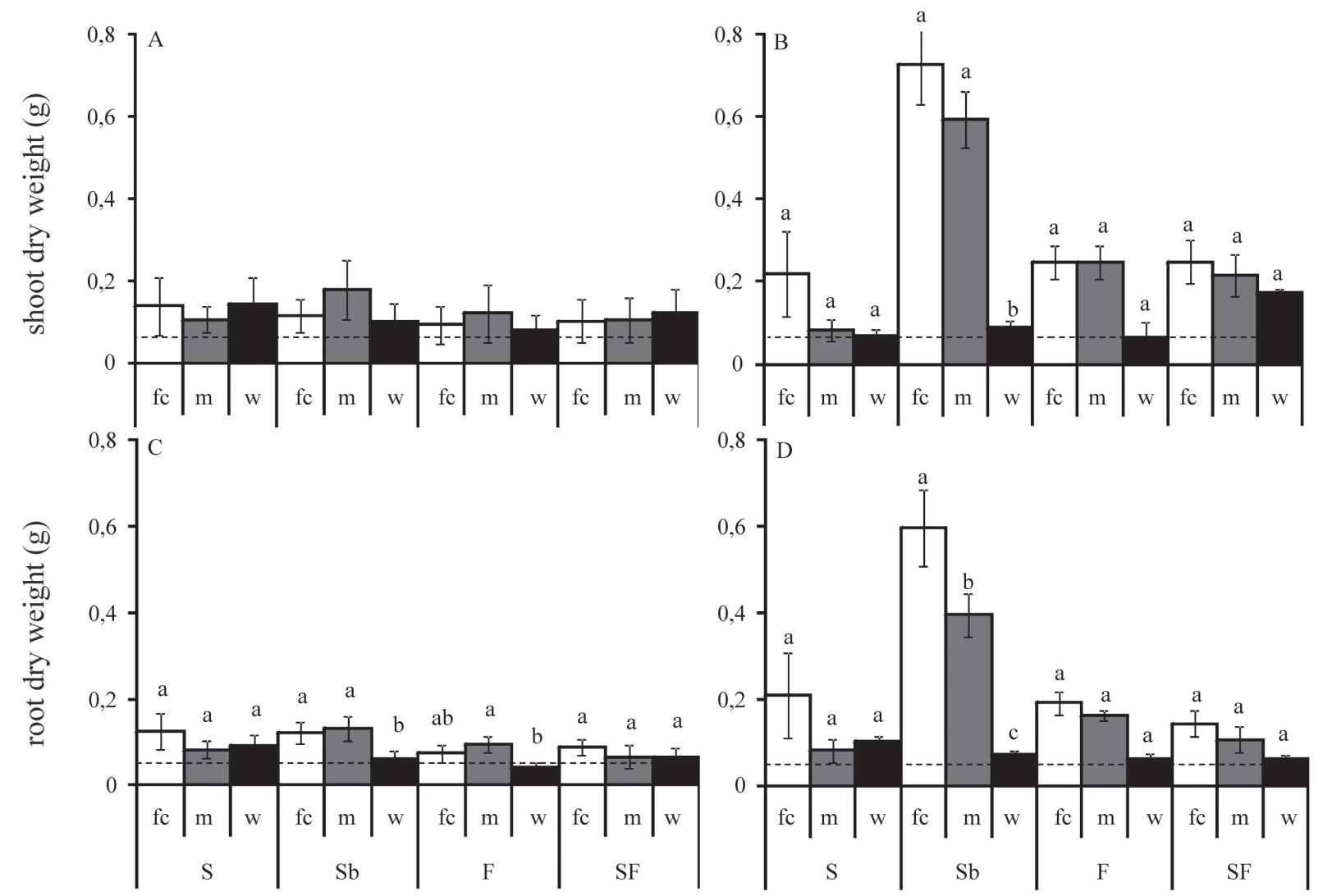

Figure 3. Shoot (graphics A and B) and root (graphics C and D) dry mass of Ocotea pulchella seedlings grown in S (100\% irradiance; $\mathrm{R}: \mathrm{FR}=1.27)$, $\mathrm{Sb}(50 \%$ shade; $\mathrm{R}: F R=1.27), \mathrm{F}(89 \%$ shade; R:FR $=0.3)$ and $\mathrm{SF}(98 \%$ shade; $\mathrm{R}: \mathrm{FR}=0.3)$, at field capacity $(\mathrm{fc})$, mean flooding $(\mathrm{m})$ and full flooding $(\mathrm{w})$. Means \pm SE. Small letters (Tukey test, $\alpha=0.05$ ) compare water treatments within each light regime. Results after three months (graphics A and C) and twelve months (graphics B and D). Dashed lines represent mean values at the beginning of the assay $\left(\mathrm{t}_{\text {zero }}\right)$.

Table 2. Root:Shoot dry mass ratio for Ocotea pulchella seedlings and juveniles grown at full sun (S) (100\% of irradiance; R:FR $=1.27)$ or covered with $\mathrm{Sb}(50 \%$ of shade; R:FR $=1.27), \mathrm{F}(89 \%$ of shade; R:FR $=0.3)$ and $\mathrm{SF}(98 \%$ of shade; R:FR $=0.3)$, and kept in substrate at field capacity (fc), mean flooding ( $\mathrm{m})$ and full flooding $(\mathrm{w})$. Data are means \pm CI $(\alpha=0.05)$ after three and twelve months from the start of the experiment $\left(\mathrm{t}_{\text {zero }}\right)$.

\begin{tabular}{|c|c|c|c|c|c|c|c|}
\hline \multirow[t]{2}{*}{ Light } & \multirow[t]{2}{*}{ Water } & \multicolumn{3}{|c|}{ Seedlings } & \multicolumn{3}{|c|}{ Juveniles } \\
\hline & & $t_{\text {zero }}$ & 3 months & 12 months & $t_{\text {zero }}$ & 3 months & 12 months \\
\hline & & $0,77 \pm 0,18$ & & & $0,80 \pm 0,10$ & & \\
\hline \multirow{3}{*}{ S } & $\mathrm{fc}$ & & $1,04 \pm 0,38$ & $1,02 \pm 0,16$ & & $0,76 \pm 0,24$ & ${ }^{*} 1,19 \pm 0,12$ \\
\hline & $\mathrm{m}$ & & $0,83 \pm 0,18$ & $1,21 \pm 0,57$ & & - & - \\
\hline & $\mathrm{w}$ & & $0,74 \pm 0,25$ & ${ }^{\star} 1,60 \pm 0,38$ & & $0,80 \pm 0,04$ & $1,00 \pm 0,63$ \\
\hline \multirow{3}{*}{$\mathrm{Sb}$} & $\mathrm{fc}$ & & $1,24 \pm 0,50$ & $0,81 \pm 0,07$ & & $0,67 \pm 0,13$ & ${ }^{\star} 1,09 \pm 0,13$ \\
\hline & $\mathrm{m}$ & & $0,85 \pm 0,32$ & $0,67 \pm 0,10$ & & - & - \\
\hline & $\mathrm{w}$ & & $0,72 \pm 0,31$ & $0,99 \pm 0,31$ & & $0,85 \pm 0,18$ & $0,69 \pm 0,11$ \\
\hline \multirow{3}{*}{ F } & $\mathrm{fc}$ & & $0,89 \pm 0,16$ & $1,02 \pm 0,35$ & & ${ }^{\star} 0,49 \pm 0,17$ & $0,68 \pm 0,18$ \\
\hline & $\mathrm{m}$ & & $0,93 \pm 0,26$ & $0,80 \pm 0,28$ & & - & - \\
\hline & $\mathrm{w}$ & & $0,56 \pm 0,15$ & $0,96 \pm 0,23$ & & $0,70 \pm 0,20$ & $0,60 \pm 0,25$ \\
\hline \multirow{3}{*}{ SF } & $\mathrm{fc}$ & & $1,03 \pm 0,36$ & $0,57 \pm 0,08$ & & ${ }^{*} 0,40 \pm 0,07$ & ${ }^{\star} 0,47 \pm 0,05$ \\
\hline & $\mathrm{m}$ & & $0,70 \pm 0,20$ & $0,57 \pm 0,19$ & & - & - \\
\hline & $\mathrm{w}$ & & $0,56 \pm 0,06$ & ${ }^{\star} 0,39 \pm 0,07$ & & $0,87 \pm 0,25$ & $0,79 \pm 0,15$ \\
\hline
\end{tabular}

${ }^{*}=$ differ from $t_{\text {zero }}$ (Tuckey test; $\left.\alpha=0.05\right)$ 

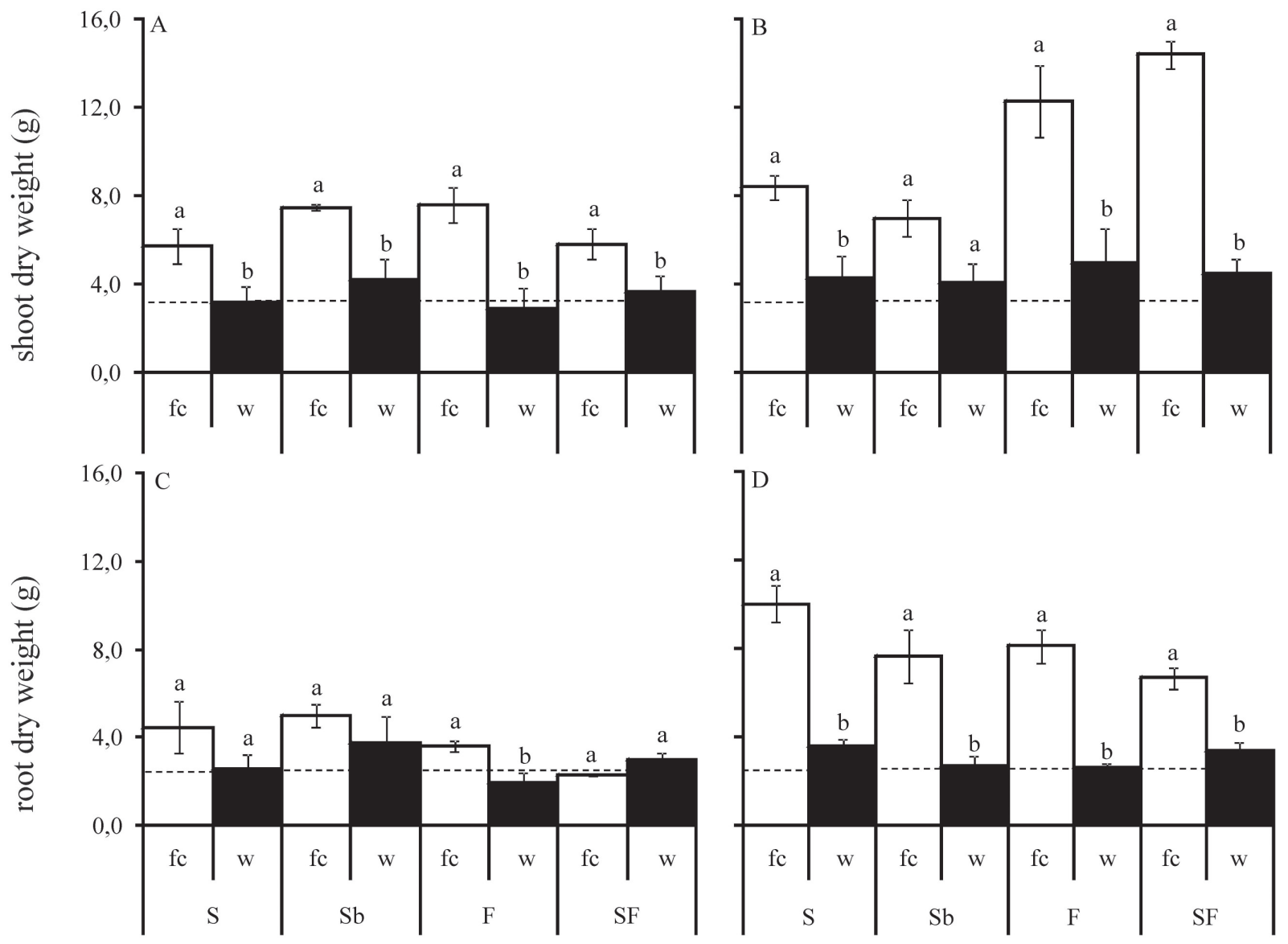

Figure 4. Shoot (graphics A and B) and root (graphics C and D) dry mass of Ocotea pulchella juveniles grown in S (100\% irradiance; R:FR $=1.27)$, Sb (50\% shade; $\mathrm{R}: \mathrm{FR}=1.27), \mathrm{F}(89 \%$ shade; R:FR $=0.3)$ and SF ( $98 \%$ shade; R:FR $=0.3)$, at field capacity $(\mathrm{fc})$ and full flooding $(\mathrm{w})$. Means \pm SE. Small letters (Tukey test, $\alpha=0.05)$ compare water treatments within each light regime. Results after three months (graphics A and C) and twelve months (graphics B and D). Dashed lines represent mean values at the beginning of the assay $\left(\mathrm{t}_{\text {zero }}\right)$.

plants under neutral shading (Figure 5A), whereas "Specific Leaf Area" (SLA) and "leaf area ratio" (LAR) in 'w' differed from ' $m$ ' but not from ' $f c$ ' (Figures 5C, E). Seedlings kept waterlogged in $\mathrm{S}$ were removed from the SLA, LAR and LWR analysis since only one plant had leaves. When compared to the beginning of the assay, the variables decreased or did not differ significantly from $t_{\text {zero }}$, except for leaf area of seedlings grown under shading at both ' $\mathrm{fc}$ ' and ' $\mathrm{m}$ ', and of the SLA and LAR of seedlings submitted to ' $m$ ' and covered with SF (Figure 5). Growth in leaf area of juveniles submitted to shading (Sb, F and SF) was significantly inhibited by flooding (Figure 5B), but in general no significant differences in SLA, LAR and LWR were observed between plants kept in field capacity and flooding, with the variables decreasing or not changing as compared to $t_{\text {zero }}$ (Figure 5).

\section{Discussion}

Three-month-old Ocotea pulchella seedlings survived better under shaded conditions than in S, suggesting that seedling survival can be more favored under canopy than in open environments, although S irradiance recorded in this work can be higher than irradiance recorded in Restinga forest gaps (Pires 2006). In general, the survival of $O$. pulchella seedlings was not affected by flooding. Those results are in agreement with the response of $O$. pulchella seeds sowed both in wet and dry soil, whose germinability in the understory of Restinga forest was higher than in gaps (Pires et al. 2009), suggesting that the species can be both flood and shade-tolerant at least in the early developmental stages. Nine-month-old $O$. pulchella plants, here referred to as "juveniles", were in turn relatively susceptible to flooding whether or not they were shaded. That greater sensitivity of juveniles to flooding as compared to the seedlings could be associated with possible stress caused by transplantation, considering the greater root development in nine-monthold as compared to two-month-old plants. Otherwise, it has been shown that flood tolerance is influenced by plant age, as exemplified by Craine \& Orians (2006) who reported that three-month-old root-flooded Pinus rigida Mill. seedlings exhibited less mortality than 15-month-old seedlings or five-year-old saplings. Thus, this work suggests 

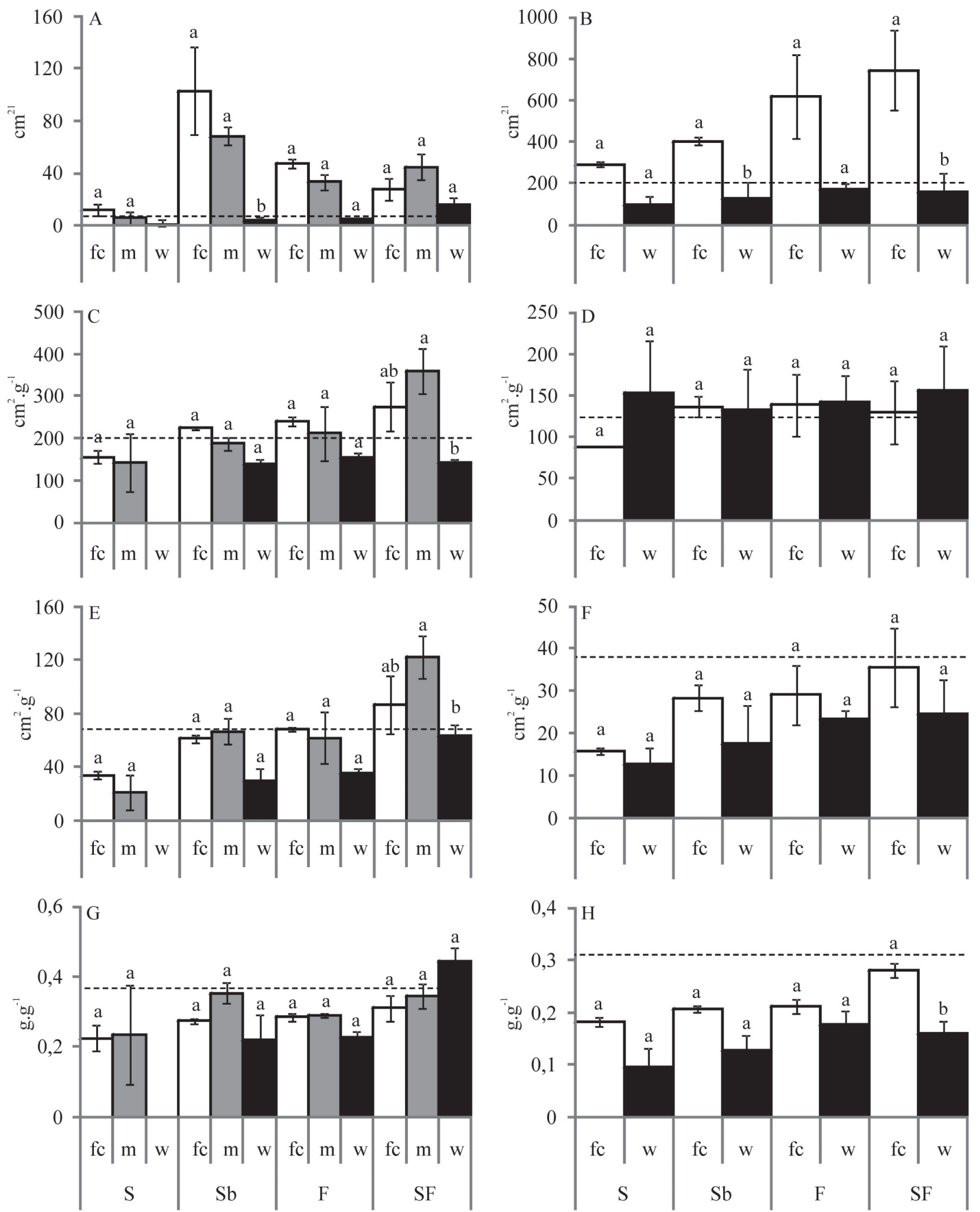

Figure 5. Leaf area (graphics A and B), Specific Leaf Area (graphics C and D), Leaf Area Ratio (graphics E and F) and Leaf Weight Ratio (graphics G and H) of Ocotea pulchella seedlings (left graphics) and juveniles (right graphics) grown in S (100\% irradiance; R:FR = 1.27), Sb (50\% shade; R:FR = 1.27), F (89\% shade; R:FR $=0.3$ ) and SF (98\% shade; R:FR = 0.3), at field capacity ( $\mathrm{fc})$, mean flooding ( $\mathrm{m}$; seedlings only) and full flooding (w). Means \pm SE. Small letters (Tukey test, $\alpha=0.05)$ compare water treatments within each light regime. Results after one year. Dashed lines represent mean values at the beginning of the assay $\left(\mathrm{t}_{\text {zero }}\right)$. 
that $O$. pulchella seedlings can survive prolonged flooding better than juveniles, and that open environments with high irradiance can be unfavorable for survival of two- and nine-month-old seedlings.

Height growth of root-flooded Ocotea pulchella seedlings was inhibited, showing that seedlings are able to remain alive but failed to grow during long term flooding (full flooding treatment) regardless of lighting conditions. The growth of shaded seedlings was not affected by "mean" flooding, whereas height growth and dry mass accumulation of plants maintained in $\mathrm{S}$ were completely inhibited in the three soil water levels, showing that direct sunlight negatively affected not only the survival but also the growth of O. pulchella seedlings. Like seedlings, root-flooded juveniles did not grow in height in any of the light treatments, whereas the growth of plants held in ' $\mathrm{fc}$ ' was inhibited both in $\mathrm{S}$ and neutral shade but not under far red enriched shade. The growth of juveniles in ' $\mathrm{fc}$ ' and under F may be related both to a lower R:FR ratio and to lower irradiance, since covering with failet not only increased far red radiation, but also decreased irradiance. It is suggested that the R:FR ratio may account for that response, considering that Tonin (2005) reported a positive effect of low R:FR ratio on the growth of nine-month-old Ocotea porosa, a co-generic species. Height growth of shaded O. pulchella plants kept in soil at field capacity was proportionally lower than shoot dry mass growth as compared to the respective initial values, probably due to the development of lateral branches and drying of the stem apical zone, which is in agreement with reports showing that the vertical growth of many trees is favored in shaded environments (Souza \& Válio 2003). That may be the case of $O$ pulchella, which is often found as small trees in open environments such as in the post-dune shrubby Restinga, and as larger trees in dense forests (Silva \& Britez 2005, Pires personal observation). Height growth of Ocotea pulchella was inhibited by long-term flooding. Otherwise considering that ' $\mathrm{fc}$ ' and ' $\mathrm{m}$ ' yielded similar results, and that flooding had practically no effect on plant growth during the first three months as compared to field capacity treatment, it is suggested that $O$. pulchella can tolerate temporary flooding. Such behavior may favor the establishment of the species in transitional and in environments subjected to soil moisture gradients such as Cerrado and Restinga, that could account for the occurrence of the species in those biomes (Lorenzi 2008). However, in order for assumptions to be made on flood tolerance of $O$. pulchella in the natural environment more assays are required concerning flood duration effects and recovery capacity of plants. Over a year, the growth in height of shaded $O$. pulchella seedlings kept both in ' $f c$ ' and ' $m$ ' was accompanied by an increase in shoot and root dry mass, whereas no growth in dry mass was observed for plants kept in flooded soil, except for seedlings covered with SF, under which the irradiance was both low and far red enriched. Although the experimental design in this work did not allow discriminating between the effects of irradiance level and red:far red ratio, the results suggest that the growth of $O$. pulchella can be favored by shading or, otherwise, it can be inhibited by full sun, suggesting possible photoinhibition.

The increase in root dry mass to shoot dry mass ratio (R:S) of flooded seedlings kept in $\mathrm{S}$ can be ascribed to leaf abscission (Pires, 2006) rather than to greater root growth, suggesting that the combined effects of $S$ and soil waterlogging had a negative effect proportionally higher on the shoot than on the roots of Ocotea pulchella. Thus, higher biomass allocation to the root may not account for the increased R:S under experimental conditions described here. Otherwise, the increase in dry mass was proportionally higher in shoots compared to roots of waterlogged seedlings kept at irradiance of $34 \mathrm{mmol} \cdot \mathrm{m}^{-2} \cdot \mathrm{s}^{-1}$ (nearly $2 \%$ of full sun) enriched with far-red light (FS), but that effect may be ascribed to the irradiance rather than to the far-red since the R:S values were higher in plants under F (failet only) than under FS, although the red to far-red ratio was the same in both treatments. An opposite effect of soil waterlogging was observed for juveniles (12-month-old plants) covered with FS, in which R:S decreased as compared to field capacity, suggesting a negative effect on the shoot as observed for $O$. pulchella seedlings grown in $\mathrm{S}$.

The increase in leaf area with shading, as reported in this work, has been found in other studies and may reveal a strategy of the plant for improving its efficiency in capturing light, ensuring that dry matter production is not affected (Figliolia 2005; Scalon et al. 2001). The results obtained here cannot be ascribed only to the lower red to far-red ratio since irradiance also decreased in the far-red enriched as compared to the neutral shading. Souza \& Válio (2003), working with seedlings of several tropical tree species differing in successional status, reported that the leaf area was smaller in natural than in neutral shading and suggest an effect of phytochrome photo-equilibrium on leaf area, but that effect remains to be tested for Ocotea pulchella. As observed for the variables height and dry mass, soil waterlogging inhibited leaf area growth in juveniles and seedlings whatever the light conditions. Taking into account the leaf variables ("leaf area", "specific leaf area", "leaf area ratio" and "leaf weight ratio") as well as shoot height and root and shoot dry mass, in general no significant differences were observed between O. pulchella seedlings kept in soils at field capacity and those kept at mean flooding, that simulate roughly the soil moisture normally found in the wettest microenvironments of the Restinga (Pires 2006). In juveniles, practically no differences were observed between the two soil water regimes concerning SLA, LAR and LWR. The latter decreased in the four light regimes as compared to $t_{\text {zero, }}$ suggesting a reduction in size of the photosynthetic apparatus probably due to the abscission of old leaves and the grown of new small-sized leaves, but except for those covered with SF the effect was not restricted to the flooded plants, which can be related to possible stress caused by transplanting prior to the start of 
the assays. The initial URL and LAR values for O. pulchella were low as compared to species only found in the moist forest (Markesteijn \& Poorter 2009), in which water is not a limiting factor and the seedlings should have characteristics related to acquisition of light. Otherwise, they were closer to the values obtained for seedlings from dry forest rather than from moist forest, which could help explain the occurrence of Ocotea pulchella both in well-drained Restinga soils and in Cerrado subjected to seasonal water deficit.

The results suggest that two- and nine-month-old Ocotea pulchella seedlings can survive in the understory, even in areas subject to periodic flooding, forming a slow-growth seedling bank which could eventually benefit from any increases of irradiance. The plant has a high capacity to survive under flooding and shading, although its growth in these conditions can be slow or null. Furthermore, twomonth-old seedlings can grow in a soil water level (referred to here as mean flooding) similar to that normally found in the wettest microenvironments of the Restinga. However long-term exposure to flooding can inhibit the growth of the species, which can account for the low density of adult individuals of $O$. pulchella in long-term waterlogged soils in Restinga (Silva \& Britez 2005). More assays are needed in order to access for tolerance of $O$. pulchella seedlings to flooding, but the results reported here suggest that the species can tolerate relatively long-term soil waterlogging when kept out of direct sunlight. Otherwise, some responses of waterlogged $O$. pulchella plants to shading seem to be affected by both light quantity (irradiance) and light quality (red to far-red ratio), although the effects of such factors have been more noticeable in plants either kept at field capacity or mean flooding.

\section{Acknowledgements}

The authors thank: CNPq and Project "Diversidade, dinâmica e conservação em Florestas do Estado de São Paulo: 40 ha de parcelas permanentes (Biota/Fapesp)" for support; and Dr. Pablo Carrasco, from Viveiro Municipal de Ilha Comprida, for providing seedlings.

\section{References}

Carvalho, P.E.R. 2006. Espécies Arbóreas Brasileiras. Brasília, Embrapa. Craine, S.I. \& Orians, C.M. 2006. Effects of flooding on pitch pine (Pinus rigida Mill.) growth and survivorship. Journal of the Torrey Botanical Society 133(2): 289-296.

Dale, M.P. \& Causton, D.R. 1992. The ecophysiology of Veronica chamaedrys, V. montana and V. officinalis. II. The interaction of irradiance and water regime. Journal of Ecology 80: 493-504.

Durigan, G.; Nishikawa, D.L.L.; Rocha, E.; Silveira, E.R.; Pulitano, F.M.; Regalado, L.B.; Carvalhaes, M.A.; Paranaguá, P.A. \& Ramilu, V.E.L. 2002. Caracterização de dois estratos da vegetação em uma área de cerrado no município de Brotas-SP-Brasil. Acta Botanica Brasilica 16(3): 251-262.

Ferreira, J.N.; Ribeiro, J.F. \& Fonseca, C.E.L. 2001. Crescimento inicial de Piptadenia gonoacantha (Leguminosae, Mimosoideae) sob inundação em diferentes níveis de luminosidade. Revista Brasileira de Botânica 24: 561-566.

Figliolia, M.B. 2005. Ecologia da germinação e desenvolvimento de mudas de Platymiscium floribundum Vog. (sacambu) - Fabaceae em viveiro e sob dossel no Parque Estadual da Cantareira, São Paulo/ SP. Tese de Doutorado. Rio Claro, Universidade Estadual Paulista.

Francisco, M.R. \& Galetti, M. 2002. Aves como potenciais dispersoras de sementes de Ocotea pulchella Mart. (Lauraceae) numa área de vegetação de cerrado do sudeste brasileiro. Revista Brasileira de Botânica 25: 11-17.

Hunt, R. 1982. Plant growth curves: The Functional Approach to Plant Growth Analysis. London, Edward Arnold.

Kozlowsky T.T. \& Pallardy, S.G. 1997. Growth Control in Woody Plants. San Diego, Academic Press.

Lobo, P.C. \& Joly, C.A. 1995. Mecanismos de tolerância a inundação de plantas de Talauma ovata St. Hill. (Magnoliaceae), uma espécie típica de matas de brejo. Revista Brasileira de Botânica 18: 177-183.

Lorenzi, H. 2008. Árvores Brasileiras: Manual de identificação e Cultivo de Plantas Arbóreas Nativas do Brasil. Nova Odessa, Instituto Plantarum.

Markesteijn, L. \& Poorter, L. 2009. Seedling root morphology and biomass allocation of 62 tropical tree species in relation to drought- and shadetolerance. Journal of Ecology 97: 311-325.

Montgomery R.A. \&.Chazdon, R.L. 2002. Light gradient partitioning by tropical tree seedlings in the absence of canopy gaps. Oecologia 131:165-174.

Pires, L.A. 2006. Ecofisiologia de espécies ocorrentes em uma floresta de Restinga. Tese de Doutorado, Instituto de Biociências, Rio Claro, Universidade Estadual Paulista "Júlio de Mesquita Filho".

Pires, L.A.; Cardoso, V.J.M.; Joly, C.A. \& Rodrigues, R.R. 2009. Germination of Ocotea pulchella (Nees) Mez (Lauraceae) seeds in laboratory and natural restinga environment conditions. Brazilian Journal of Biology 69: 935-942.

Rodrigues, R.R. \& Naves, A.G. 2001. Heterogeneidade florística das matas ciliares. In: Rodrigues, R.R. \& Leitão-Filho, H. (Eds.). Matas Ciliares: Conservação e Recuperação. São Paulo, FAPESP.

Salimon, C.I. \& Negrelle, R.B. 2001. Natural regeneration in a quarternary coastal plain in the southern Brazilian Atlantic Rain Forest. Brazilian Archives of Biology and Technology 44: 155-163.

Scalon, S.P.Q.; Scalon Filho, H.; Rigoni, M.R. \& Veraldo, F. 2001. Germinação e crescimento de mudas de Pitangueira (Eugenia uniflora L.) sob condições de sombreamento. Revista Brasileira de Fruticultura 23: 652-655.

Silva, S.M. \& Britez, R.M. 2005. A vegetação da planície costeira. In: Marques, M.C.M. \& Britez, R.M. (Orgs.). História Natural e Conservação da Ilha do Mel. Curitiba, Editora UFPR.

Souza, R.P. \& Válio, I.F.M. 2003. Seedling growth of brazilian tropical tree species differing in successional status. Revista Brasileira de Botânica 26: 35-47.

Sugyama, M. 1998. Estudo de florestas da restinga da Ilha do Cardoso, Cananéia, São Paulo, Brasil. Boletim do Instituto de Botânica 11: 119-159.

Tonin, G.A. 2005. Efeito da época de coleta, condições de armazenamento, substratos e sombreamento na emergência de plântulas e produção de mudas de Ocotea porosa (Ness et Martius ex Nees) (Lauraceae) e de Sapindus saponaria L. (Sapindadeae). Tese de Doutorado, São Carlos, Universidade Federal de São Carlos.

Walker, L.R. \& Chapin, F.S. 1986. Physiological controls over seedling growth in primary succession on an alaskan floodplain. Ecology 67: 1508-1523.

Zar, J.H. 1996. Biostatistical Analysis. New Jersey, Prentice Hall. 